Jonathan S. Milgram

\title{
From Mesopotamia to the Mishnah
}

\section{Tannaitic Inheritance Law in its Legal and Social Contexts}

[Von Mesopotamien zur Mischna. Tannaitisches Erbrecht in seinen rechtlichen und gesellschaftlichen Kontexten.]

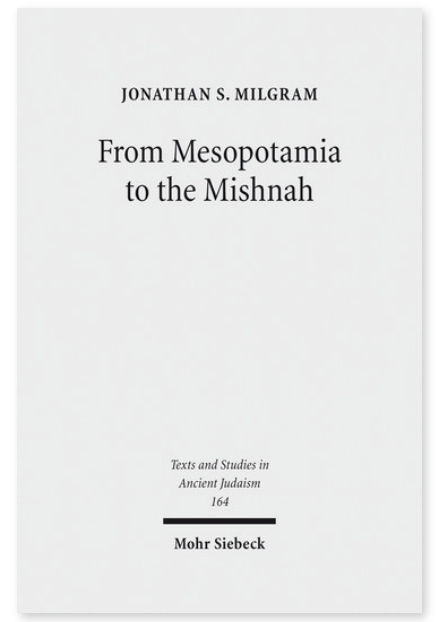

2016. XXI, 201 Seiten. TSAJ 164

ISBN 978-3-16-154421-7

DOI 10.1628/978-3-16-154421-7

eBook PDF 134,00 €

ISBN 978-3-16-154021-9

Leinen $134,00 €$
Veröffentlicht auf Englisch.

Jonathan S. Milgram zeigt, dass die Umwandlung des Erbrechts von der biblischen zur tannaitischen Zeit am besten vor dem Hintergrund der rechtlichen und gesellschaftlichen Zusammenhänge erklärt werden kann, in der die tannaitischen Gesetze formuliert wurden. Dazu stellt der Autor Gesetze in anderen antiken Gesetzestraditionen dar, die von den Tannaim übernommen und angenommen wurden und erwägt das Ausmaß, in dem tannaitische Gesetze aus den sozialen und wirtschaftlichen Gegebenheiten des tannatischen Palästina entsprungen sein könnten.

Jonathan S. Milgram Born 1971; 1995 BA, Columbia University; 1995 BA, The Jewish Theological Seminary; 1997 MA, Yeshiva University; 2002 Rabbinic Ordination, Yeshiva University; 2007 PhD, Bar Ilan University; formerly Sam and Vivienne Cohen Lecturer in Jewish Studies, The School of Oriental and African Studies, University of London (UK) and Fellow, London School of Jewish Studies; currently Associate Professor of Talmud and Rabbinics, The Jewish Theological Seminary.

\section{Jetzt bestellen:}

https://mohrsiebeck.com/buch/from-mesopotamia-to-the-mishnah-9783161544217?no_cache=1 order@mohrsiebeck.com

Telefon: $+49(0) 7071-923-17$

Telefax: $+49(0) 7071-51104$ 